\title{
THE NOTION OF IDIOSTYLE IN LINGUISTIC STUDIES OF LITERARY TEXTS
}

\author{
Iryna Sydorenko \\ Kyiv, National Technical University of Ukraine \\ "Igor Sikorsky Kyiv Polytechnic Institute" \\ sydiryna@gmail.com
}

\begin{abstract}
The article highlights peculiarities of the author's individual style investigation as a part of literary text stylistics. Main attention is given to the approaches to individual style study and its place in linguistic researches of literary texts. The research aim is obtained with the help of scientific methods: generalization, conceptualization and comparison of the directions of idiostyle study in order to define the most appropriate approach for outlining the idiostylistic peculiarities of the literary texts authors. The analysis of early and current publications exploring the idiostylistic peculiarities of the author's speech is presented. Ten basic tendencies in idiostyle investigation are separated, analyzed and compared. The conducted exploring provides the possibility to reveal that studying the language of literary texts through the prism of the author's speech analysis is one of the most relevant tasks of modern linguistics. A comparative analysis indicates that one of the most common areas of its study today is the analysis of the author's conceptual sphere in combination with the study of stylistic techniques, syntax and individual vocabulary. The combination of several approaches within a single study makes it possible to describe the peculiarities of idiostyle of a literary text writer and provide a complete understanding of the selection and synthesis principles of linguistic means by a certain author, reveal the prevailing features and outline a prototype of the individual speech model. The prospect of research is considered in defining the approaches to the author's idiostyle study in dramatic genre.
\end{abstract}

Key words: literary text; author's idiostyle; lingvostylistic research; scientific approach; author's speech model.

Introduction. The language of literary works has always been the subject of research since the formation of philological thought as a science. At the end of the nineteenth and at the beginning of the twentieth century the scholars were focused mainly on the types and means of formal connectivity of literary speech as well as on the peculiarities of its structural organization and syntactic filling within one text (Budde, Scherba, Shpet) which did not allow to describe such a complex phenomenon as the style of literary language thoroughly and comprehensively. Subsequently, the introduction of the concepts of "linguistic consciousness" (Humboldt, Potebnja) and "linguistic picture of the world" (Humboldt, Weissgerber) into linguistics created the preconditions not only for studying the literary text as an integrated structure, but also for its perception and study as the specific anthropocentric communicative model determined primarily by the peculiarities of the author's worldview and language. The analysis of the stylistic system of the literary text through the prism of author's linguistic personality (the term being introduced by Karaulov in 1989) became one of the integrant aspects of the literary language studying. In its turn, the problem of individual author's stylistics, its place in the system of already functioning verbal means and role in the realization of the unique pragmatic potential of the literary work and the author in general have become the basis for numerous studies in linguostylistics which indicates the relevance of present work. At the same time, there is still no defined and unified classification of the approaches to the study and interpretation of the category of "individual style" of the author of the literary text in today's scientific environment which determines the novelty of given article.

Methods. The phenomenon of linguistic personality and the concept of the individual style of the author of the literary text became the subject of extensive and profound research for many native and foreign scholars beginning from the second half of the twentieth century, namely Ahmanova (1966), Bahtin (1986), Bloch (1948), Bloomfield (1973), Drozdovskij (1972), Fowler (1977), Grigor'ev (1983), Kukharenko (1974), Larin (1974), Preobrazhenskiy (1991), Shhukin (1984), Vinogradov (1961), Vinokur (1991). The conducted analytical review of modern scientific works devoted to the study of the aforementioned notion indicates that in recent years interest to given issue has increased significantly. Thus, the concept of idiostyle of the author is considered in scientific, including dissertational, works of such native researchers as Bachyshyna (2016), Bezrebra (2007), Bugoslavs`ka (2017), Dojchyk (2012), Golovchenko (2011), Jermolenko (2001), Jurina (2016), Loschynova (2016), Lyntvar (2015), Makar (2010), Pivenj (2007), Shapoval (2015), Shatilova (2011), Skyba (2013). Among foreign philologists who are addressing to the interpretation of individual stylistic language means we single out Bolotnova (2009), Dragaleva (2013), Freeman (2000), Grishchenko (2008), Hayzen (2006), Klovak (2015), Lezhneva (2013), Muhin (2010), Pankratova (2009), Semino (2007), Severskaja (2007), Shestakova (2001), Sivkova (2007), Solganik (2009), Stokwell (2002), Tarasova (2004), Zahidova (2009).

The aim of the article is obtained through these scientific methods: generalization, systematization and classification of methodological sources and scientific approaches to the study of the concept of "idiostyle" 
in the system of linguistic analysis of literary texts in scientific works of Ukrainian as well as foreign researchers. The main tasks are to define the aforesaid approaches, to identify the most distinguishing features of each approach, to conduct their conceptual and comparative analysis which will allow the most detailed study of the idiostylistic peculiarities of the authors of literary texts. The object of given exploring is idiostyle; the subject is its research.

Results. We consider it worthwhile to note that the vast majority of researchers consider the terms "individual style" and "idiostyle" synonymous, but some still state that notion of "idiostyle" is more modern than "individual style" since it means new and broader, according to its content, linguistic phenomenon (Bolotnova 2007, Chernyk 2016). In addition, recently we can observe the unfolded discussions on the delimitation of the concepts of "idiostyle" and "idiolect" in academic circles. While in linguistic terminology dictionaries and in the works of single researchers (Baranov 1997, Grigor'ev 1983, Kostecjka 2014) aforementioned definitions almost coincide, most modern linguists come to the conclusion that idiolect of the author as a combination of only linguistic forms of individual speech is a narrower concept than idiostyle and can be considered as a constituent of the latter.

The analysis of the scientific works devoted to the study of author's individual speech indicates that most researchers understand and interpret the concept of "idiostyle of the author" following Vinogradov as a complex, multilevel, but structurally connected and internally linked system of specific language stylistic means and forms of verbal creative expression inherent in the textual activity of a certain author when creating his own artistic world (Vinogradov, 1971, p.105). The scientist himself, in particular, notes that individual style is the individual use of various linguistic means in new functions depending on the linguistic taste of the writer, a peculiar selection of these means, an individual synthesis of forms of speech expression and content plan (Vinogradov, 1971, p.107). However, there are other, unique and worthwhile attempts to determine the aforementioned term. Idiostyle as a system of individual speech cognitive mechanisms and associative semantic fields of the text space creation is considered in the research of Bolotnova (Bolotnova, 2009, p. 70). According to the definition by Fomenko, idiostyle of the writer is a communicative and cognitive space of linguistic personality which creates artistic discourse modelling a lingvo-typological variant of the literary text of a certain period (Fomenko, 2006, p. 9). Idiostyle as a definitely organized structure is considered by Fateeva. The researcher interprets given notion as a combination of inner textforming dominants and constants while highlighting four types of its structural elements: situational, conceptual, operational and compositional "metatropes" that are the framework of the author's individual style and form a hierarchically ordered but, at the same time, closed system (Fateeva, 2000, p. 73). Noteworthy is the thesis by Samohina who states that study of idiostylistic features of the author must also take into account individual, socio-historical, national, psychological, moral and ethical norms of a certain period, the peculiarities of the world perception of a person and knowledge about the world, which the researcher perceives as a unique author's conceptual picture of the world, the thesaurus (Samohina, 2008, $\mathrm{p}$. 15). In this regard, it is appropriate to mention Bahtin who wrote that individual style of the author, his individual and creative consciousness is not determined only by linguistic means. Style is not a language in its narrow sense but, first of all, an aesthetic perception and author's feeling about his work as an instrument for a new artistic reality creation (Bahtin, 1986, p. 177).

According to the results of the previous analysis of scientific directions to the linguistic study of author's idiostyle we outline ten approaches which, in our opinion, provide the most complete characterization of individual style as a composite element of the stylistic system of literary text, namely: structural, aesthetically marked, figuratively-compositional, pragmasemantic, communicative-cognitive, linguostylistic, lexical, linguocreative, linguostatistical and linguotypological. Given approaches are united by a common subject of study (idiostyle) with a difference in the aspects of its consideration in accordance with different goals and objectives of scientific researches. At the same time, we can observe the tendency that even within the same approach the schemes of analysis can be rather different.

The first direction is marked by the focus on the structural study of the literary text style in which the image of the author occupies the central place. The holistic conception of the author's image as a stylistic centre of a separate work and the writer's works in general was developed by Russian scientists of the last century (Bahtin 1986, Brandes 2004, Grigor'ev 1983, Kukharenko 1974, Novikov 1988, Vinogradov 1981). One of the main tasks of discovering the internal unity of stylistic means of literary texts, by Bahtin and Vinogradov, is the problem of the linguistic structure of the author's image (Bahtin, 1986, p. 183). Moreover, Vinogradov underlines that the internal connection of all elements of idiostyle forms a kind of literary and artistic unity due to the tendencies of various artistic genres. The linguistic styles are combined with such genres and diverse in their stylistic character speech means can be included to the stylistic forms of such genres. This is reflected in the structure of the author's image which acts as a concentrated embodiment of the work content which unites the entire system of language structures of the characters in their relationship 
with the writer (Vinogradov, 1981, p. 90).

In the studies by Kukharenko three paradigms in which a literary text is included are outlined: genre, stylistic and individual one. Regarding the third paradigm, the researcher comes to the conclusion that the author's individuality is manifested in his individual-artistic style, the core of which is seen in the author's image that, in its turn, causes the development of the work concept (Kukharenko, 2004, p. 82). Following the aforementioned scholars, Novikov argues that expressing the essence of a literary work and concentrating its ideological, compositional, structural and stylistic unity the author's image is the most important category for the holistic comprehensive analysis of the literary text language as a component of the aesthetic genre speech system (Novikov, 1988, p. 13).

The conducted analytical revision of scientific resources indicates that in recent years interest to the concept of the author's image in the plane of idiostyle study has not decreased both among Ukrainian and foreign scientists. Notable investigations concerned with the issue of author's style are scientific works by Babenko (2003), Bolotnova (2007), Pinzhenina (2011) and Sokolovsjka (2013). The latter emphasizes that the image of the author is one of the central categories of the communicative stylistics of the text. This is due to the ability of this category expressing the essence of the artistic work to combine its compositional, linguistic and stylistic peculiarities into inseparable unity (Sokolovsjka, 2013, p. 223).

In contrast to the previous approach to the study of author's style, the aesthetically-marked direction of idiostylistic researches is associated with aesthetic modification of the specific language expressive means of the writer as a prerequisite for his individual author's method formation. The object of research, as a rule, becomes key images and symbols, their role in reproducing the writer's world perception. Beginning from the twentieth century this direction was developed in the works of such Ukrainian and foreign linguists as Bally (1909), Jermolenko (1982), Kozhevnikova (1999), Larin (1974), Peshkovskij (1930), Stavycjka (2009), Vinokur (1991). The aesthetic study, by Larin, is the least prejudiced of all and the author's style can only be determined on the basis of speech aesthetics (Larin, 1974, p. 52). According to the definition by Jermolenko, the individual style is a "collection of language-expressive means that perform the aesthetic function and distinguish the language of a separate writer among others" (Jermolenko, 1982, p. 304).

According to the conducted quantitative analysis, we establish that attention of the scientists to the aforementioned direction has slightly decreased. Yet, new aspects in the study of the aesthetics of author's speech are opened in explorings by Ukrainian and foreign researchers such as Domylivsjka (2011), Ledeneva (2001), Olifirenko (2002), Perelomova (2002). Author's individual method is determined by Ledeneva only on the basis of the aesthetic activity of the linguistic personality and as the key category in defining idiostyle the aesthetic superiority which is based on the qualities of the author's aesthetic pragmatic vocabulary is submitted (Ledeneva, 2001, p. 36). Investigating the linguistic and aesthetic role of phonical means Olifirenko outlines the ratio of the general and individual in the structure of poetic works by Vasyl Stus (Olifirenko, 2002, p.4). In her dissertation Domylivsjka considers idiostyle as a linguistic aesthetic phenomenon taking into account extra- and intro-linguistic criteria manifested in works by Yanovsky, primarily, in the aesthetic nature of the author's linguistic symbol. (Domylivsjka, 2011, p. 4)

Representatives of the figuratively-compositional direction focus on the peculiarities of individual style in terms of unique individual dynamics of speech forms, figurative transformation of text formation and compositional methods of text building. This approach was initiated in the works by Russian linguists Domashnev (1989), Vinogradov (1981), Vinokur (1991).

The analysis of recent works devoted to the study of the author's idiostyle through the prism of text composition indicates that their number is rather limited. Among them, we can distinguish Russian researchers Djakonov (2002), Ivanov (2012), Kalinina (2009), Novikov (2011), Solganik (2009). In particular, Solganik distinguishes an individual style in the building of the prose verse and in the paragraph division of the compositional-syntactic structure of the text. The scientist considers the prose passage as the smallest artistic unity. Every author, by Solganik, has its relatively constant type closely associated with his artistic method. The researcher considers the paragraph as an important idiostylistic tool of allocation, graphic representation of syntactical units, the tool of content and stylistic division of the text (Solganik, 2009 , p. 231). In her turn, Kalinina in her dissertation research argues that the analysis of the construction of separate sentences and the whole text allow us to conclude about the idiostyle of the author, to determine his hidden intentions (Kalinina, 2009, p. 6).

At the beginning of the XXI century we can observe the transition from the text-centric to the discoursecentric approach concerning textual analysis as a result of personality factor actualization in language and interpretation of the artistic text as a special way of communicative interaction between the author and the addressee (reader) (Arnold 2006, Bartes 1968, Bondarenko 2008, Kondratenko 2001, Samokhina (Dmytrenko) 2006, Schmid 2003, Selivanova 2006). The researchers began to address to the new paradigms of artistic discourse analysis, primarily to linguopragmatic and discourse-cognitive ones. With regard to the 
study of idiostyle through the prism of the specificity of the author's text activity relative to the addressee the conducted review of scientific works indicates that studies of this type are usually carried out in two directions - pragmasemantic and pragmacognitive.

Directing their research in the pragmasemantic course scholars (Adah, 2009; Golikova, 2014; Kishchenko, 2014; Kotova, 2000; Loshchynova, 2016; Palijchuk, 2011; Svincova, 2016) are trying to identify pragmatic intentions, strategies, tactics and factors of the effectiveness of poetic communication that are able to make an appropriate artistic (aesthetic) influence on the reader. Thus, Kotova (2000), in her dissertational research, attempts to reveal the pragmatic essence of semantic and grammatical transpositions in the figurative structure of a poetic text, to determine their role in the general pragmatic semantic model of Gumilev's idiostyle (p. 4). In her turn, Palijchuk (2011) while investigating the idiostyles of Moem, Henry Mansfield reveals and classifies the linguistic means of the narrative code of intimization in English literary discourse as well as analyzes the communication tactics of reducing the distance between the author and the reader (p. 13).

While researching the communicative-cognitive approach to the study of author's idiostyle we come to the conclusion that it includes identification and systematization of the dominant conceptual models inherent in a particular author' style and various linguistic means of their representation on the basis of the individual cognitive space reconstruction. On the expediency of using the linguistic-cognitive approach in the study of a literary text in order to fathom the linguistic implementation of the author's plan was emphasized in studies by Fowler, Lotman, Potebnja. Later, given theory was developed in the works by Belehova (2002), Karasyk (2007), Kukharenko (2004), Selivanova (2006), Semino (2002), Vorob'eva (1993). In particular, Kukharenko believes that the author's style is determined by what is fixed with the help of numerous means of reality actualization which operate at different levels of the artistic structure, that is, concepts. It is the latter that is the dominant factor that allows the reader to interpret the text adequately (Kukharenko, 2004, p. 188).

Over the last decade given approach has become extremely relevant and widely used in the study of literary language and idiostyle of the author as well. Distinguishable studies are considered to be the works by Bajolj (2008), Bolotnova (2009), Broslavskaja (2012), Dojchyk (2012), Goloborodko (2010), Golojoh (2011), Malneva (2012), Mazepova (2007), Shevchenko (2012), Sivkova (2007), Tarasova (2012). The application of conceptual analysis and cognitive techniques in the dissertational research enabled Mazepova to determine the features of cognitive level of the poet as a linguistic personality. The analysis of the language implementation of key concepts and the specifics of the use of various linguistic means highlighted its verbal-semantic level (Mazepova, 2007, p. 20). The task of describing the notion of idiostyle Tarasova (2012) sees in its relation with the notion of concept and interprets the individual style of the author as the unity of the mental and linguistic, the concepts and cognitive structures of their linguistic embodiment (p. 9).

The study revealed that some researchers combine pragmatic and cognitive approaches. For example, in her dissertation Babych (2017) tried to develop a methodology for analyzing language means of expression, linguistic and cognitive mechanisms of formation and pragmatic strategies for the functioning of lyrical I in idiodiscourses by Frost and Sandberg (p. 109).

Another direction in the study of idiostyle is its analysis from the standpoint of functional stylistics. Representatives of given direction, which we define as linguostylistic one, focus their attention on the principles of selection and synthesis of stylistic linguistic means by the author, the nature of associations, the domination of certain lexical, grammatical, phraseological and syntactic expressions, stylistic tropes and figures. Sometimes, the objects of study become, also, the plot peculiarities. This direction was initiated in the fundamental works by native and foreign researchers such as Bulahovskij, Vinogradov, Potebnja, and later developed by such linguists as Bilodid (1968), Kotjurova (2003), Macjko (2003), Sologub (1991), Stavycjka (2009).

The conducted analytical review of scientific resources indicates that the linguostylistic study of idiostylistic peculiarities of literary works does not lose its relevance today attracting the attention of many scholars. Among them, we can distinguish Ukrainian and Russian scholars such as Lyntvar (2015), Pivenj (2007), Shatilova (2011), Jurina (2016). In particular, Yurina studying the language of Olena Teliga, concludes that idiostyle is a verbal implementation of the unique author's picture of the world in the system of language dominants (phonetic, lexical, phraseological, grammatical) caused by his ideological orientation, constant style forming features which determine the specifics of the artistic system (Jurina, 2016, p. 14).

In some studies (Bezrebra, 2007; Brailko, 2005; Danyljchuk, 2006; Gryshchenko, 2013; Kotkova, 2017; Pankratova, 2009), we find the combination of linguostylistic approach with other abovementioned approaches. Thus, in her dissertation, Bezrebra studies the stylistic and semantic-cognitive aspects of E. Dickinson's poetry and investigates the idiostyle as a way of representing the artist's outer and inner world in speech using an individual system of expressive means and stylistic techniques that provide the specific imagery of author's poetic texts. Idiolect and idiostyle are investigated within the stylistic aspect of exploring 
by analyzing verbal units of poetic texts by Dickinson. The range of linguistic study of expressive means and stylistic techniques is expanded by the additional introduction of elements of parallel consideration of verbalpoetic images and extra-language context (Bezrebra, 2007, p. 8). The investigation of the individual-author's styles of British and American poetry of the XVII ${ }^{\text {th }}-\mathrm{XX}^{\text {th }}$ centuries was also done by Gryshchenko (2013) through the lens of pragmatic and cognitive approaches (p. 5). In her turn, Kotkova (2017) examines the idiolect of Volodymyr Vynnychenko in the context of identifying the system of stylistic individual constants and dominants that depict specific ways of fragments verbalization of the conceptual picture of the world representing the sensory sphere, worldview and the originality of writer's thinking. The researcher considers lexical and phraseological means of verbalization of the conceptual sphere of idiolect as well as the stylistic characteristics of the idiostylistic system of expressive means (Kotkova, 2017, p. 7).

Analyzing the scientific explorings of the last decade, we come to the conclusion that the approach to the writer's idiostyle study through the analysis of author's lexical idiosystem also deserves attention. In this regard, the dissertational works by Makar (2010), Petryshyn (2005), Strokalj (2011), Tymejchuk (2007) are believed to be noteworthy. Thus, investigating the idiostyle of Long Makar comes to the conclusion that it is the lexical system of the literary work that is its integral constituent (Makar, 2010, p. 14). In her turn, Strokalj is convinced that idiostyle of the writer is a combination of those or other means by which the author embodies certain intentional dominants in the linguistic reality, verbalizes certain artistic ideas which can be expressed only by a special combination of words and sounds constituting the real meaning of the artistic work (Strokalj, 2011, p. 7).

Somewhat similar are considered to be the studies by Berestiuk (2008), Bugoslavs`ka (2017), Gryshchenko (2008) in which the creativeness of linguistic activity of the writer is presented as the main element of his idiostyle. The objects of research, in this case, are author's neologisms, occasionalisms, nonvisual grammatical forms and a language game.

According to some modern researches, the statistical characteristics of literary text as the formal properties of its structure allow to determine objectively the qualitative characteristics of idiostyle. Therefore, the main attention is concentrated not on the content filling of the work, but on the peculiarities of the author's style in terms of statistic data. Linguostatistical method is argued to allow a complete quantitative description of the literary text (Muhin 2011, Pavlychko 2010).

In the course of the linguotypological study of idiostyle the investigations by Fomenko (2006) and Klovak (2015) are performed. The subject of Klovak (2015) study is idiostyle as a complex system of typical author's models that regulate the reader's reflections and lead to an adequate understanding of the content of the author's text. The hypothesis of the study is that there is a system of typical individual models in the literary text of any author that have parameters of frequency, stability, possess certain semantic potential and a stable connection with the performed function in the text in all author's writings (Klovak, 2015, p. 4).

Discussion. The aforementioned directions of scholarly research comprehensively cover the concept of idiostyle and its place in the stylistic system of the literary work language. However, taking into consideration the fact that the individual style is a complex multilevel category, the combination of several approaches within a single study, as far as we are concerned, makes it possible not only to describe the peculiarities of the individual speech of a writer more deeply, but also to provide a complete understanding of the principles of selection and synthesis of stylistic linguistic means by a certain author, reveal the prevailing and the most characteristic features of his works, outline a prototype of the individual-author's speech model.

Conclusions. The conducted exploring reveals that studying the language of literary text through the prism of the author's speech model analysis is one of the most significant and relevant tasks of modern linguistics. Ten approaches are defined and described in the course of which the idiostyle research has been conducted and is still being conducted among native and foreign scientists. We unite given approaches according to a common subject of investigation (idiostyle) and common aspects of its consideration. It allows us to conclude that the basis for modern studies of idiostyle is the study of the role of the author's image, which still has not lost its relevance. Such concepts as aesthetically marked speech-expressive means, the pragmatics of author's speech, the conceptual idiosphere of the author, the cognitive level of linguistic personality, the language game, and author's syntagmatics are in the centre of recent researches. A comparative analysis of the aforementioned approaches indicates that one of the most common areas of idiostyle study today is the study of the author's conceptual sphere in combination with the study of the peculiarities of the use of stylistic techniques, syntax organization and individual vocabulary.

The scjpe for further research we consider in defining the approaches to the author's idiostyle study in dramatic genre.

\section{REFERENCES:}

1. Babych, V. I. (2017). Movnostylistychni zasoby vyrazhennja lirychnogho Ja na leksyko-ghramatychnomu rivni poetychnogho tekstu (na materiali idiodyskursiv R. Frosta $j$ K. Sendbergha) [Linguo-stylistic means of expression of lyrical i at 
lexical and grammatival level of a poetic text (based on idiodiscourses of R. Frost and C. Sandberg)]. Naukovyj visnyk Khersonsjkogho derzhavnogho universytetu, 3, 109-116.

2. Bahtin, M. M. (1986). Jestetika slovesnogo tvorchestva [Aesthetics of the wordy creation]. Moscow, Russia: Iskusstvo.

3. Bezrebra, N. Ju. (2007). Linhvostylistychnyi ta Semantyko-Kohnityvnyi Aspekty Poetyky E. Dikinson [Linguostylistic and semantic-cognitive aspects of E. Dikinson poetics]. Extended abstract of $\mathrm{PhD}$ dissertation, Kyiv, Ukraine.

4. Bolotnova, N. S. (2009). Kommunikativnaya stilistika teksta: slovar-tezaurus [Communicative Stylistics of the Text]. Moscow, Russia: Flinta, Nauka.

5. Domylivsjka, L. V. (2011) Idiostyl' Yuriia Yanovskoho v konteksti linhvoestetychnykh paradyhm pershoi polovyny XX st. [The Yurii Yanovskii's Individual Style through the System of Language and Aesthetic Paradyghms at the Beginning of the 20th Century]. Extended abstract of PhD dissertation, Kyiv, Ukraine.

6. Fateeva, N. A. (2000). Kontrapunkt intertekstual'nosti, ili Intertekst v mire tekstov [Contrapoint of intertextuality or Intertext in the world of texts]. Moscow, Russia: Agar.

7. Fomenko, Je. G. (2006). Lingvotipologicheskoye v idiostile Dzheymsa Dzhoysa [Linguo-Typological Properties of James Joyce's Idiostyle]. Extended abstract of $\mathrm{PhD}$ dissertation, Zaporozhye, Ukraine.

8. Gryshchenko, Ja. S. (2013). Dy`skursy`vnist`virshovany`x tvoriv: kognity`vno-pragmaty`chny`j vy`mir (na materiali anglijs `koyi ta amery`kans `koyi poeziyi XVII - XX stolit`) [Cognitive and Pragmatic Aspect of Poetry Discursiveness in English and American Verses of the $17^{\text {th }}-20^{\text {th }}$ Centuries]. Extended abstract of PhD dissertation, Kyiv, Ukraine.

9. Jermolenko, S. Ja. (1982). Syntaksys $i$ stylistychna semantyka [Syntax and stylistic semantics]. Kyiv, Ukraine: Naukova dumka.

10. Kalinina, Ju. M. (2009). Kompozicija hudozhestvennogo teksta kak sredstvo vyrazhenija ego antropocentrichnosti [Literary text composition as a mean of its anthropocentricism expression]. Extended abstract of PhD dissertation, Lipeck, Russia.

11. Klovak, E. V. (2015). Tipichnye avtorskie modeli kak realizacija universal'nogo $i$ individual'nogo $v$ idiostile [Typical author's models as realization of general and individual in idiostyle]. Extended abstract of PhD dissertation, Tver', Russia.

12. Kotkova, L. I. (2017). Idiolekt Volodymyra Vynnychenka: leksyko-frazeologhichni ta stylistychni skladnyky [Volodymyr Vynnychenko idiolect: lexic-phraseological and stylistic components]. Extended abstract of PhD dissertation, Nizhyn, Ukraine.

13. Kotova, A. G. (2000). Pragmasemanticheskie aspekty idiostilja N. S. Gumileva :Na materiale pojeticheskih proizvedenij [Pragmasemantic aspects of Gumilev idiostyle : on the material of poetry]. Extended abstract of PhD dissertation, Volgograd, Russia.

14. Kukharenko, V. A. (2004). Interpritacija teksta [The text interpretation]. Vinnycja, Ukraine: Nova Knyga.

15. Langacker, Ronald W. (1991). Concept, Image, and Symbol: The Cognitive Basis of Grammar. Berlin: Mouton de Gruyter. http://dx.doi.org/10.1515/9783110857733

16. Larin, B. A. (1974). Jestetika slova i jazyk pisatelja [Aesthetics of speech and language writer]. Moscow, Russia: Fiction.

17. Ledeneva, V. V. (2001). Idiostil' ( $k$ utochneniyu ponyatiya) [Idiostyle (to Clarify the Concept)]. Filologicheskiye nauki, 5, 36-41.

18. Makar, I. S. (2010). Leksy`chna idiosy`stema romanu Longa Dafnis i Xloya [Lexical Idiosystem of Longus's Novel "Daphnis and Chloe"]. PhD dissertation, Lviv, Ukraine.

19. Mazepova, O. V. (2007). Lighvistychni osoblyvosti idiostylju Sokhraba Sepekhri [Linguistic peculiarities of Sokhrab Sepekhri idiostyle]. Extended abstract of PhD dissertation, Kyiv, Ukraine.

20. Narrog, H. (2012). Modality, subjectivity, and semantic change. A cross-linguistic perspective. Oxford: Oxford University Press. https://doi.org/10.1093/acprof:oso/9780199694372.001.0001

21. Novikov, L. A. (1988). Hudozhestvennyj tekst i ego analiz [Literary text and its analysis]. Moscow, Russia: Russkij jazyk.

22. Olifirenko, L. V. (2002). Movna estetyka poeziji Vasylja Stusa [Language aesthetics of Vasyl Stus poetry]. Extended abstract of $\mathrm{PhD}$ dissertation, Donetsk, Ukraine.

23. Palijchuk, A. L. (2011). Naratyvnyj kod intymizaciji [Narrative code of intimization]. Extended abstract of PhD dissertation, Kharkiv, Ukraine.

24. Samohina, V. A. (2008). Sovremennaja anglojazychnaja shutka [Modern English joke]. Har'kov, Ukraine: HNU.

25. Sokolovsjka, S. F. (2013). Obraz avtora u khudozhnjomu tvori [The Author's Image in a Piece of Fiction]. Zhytomyr, Ukraine: Visnyk Zhytomyrsjkogho derzhavnogho universytetu, 5 (71), 222-226.

26. Solganik, G. Ja. (2009). Stilistika texta [Text stylistics]. Moscow, Russia: Nauka.

27. Strokalj, O. M. (2011). Indy`vidual`no-avtors ke slovo v sy`stemi xudozhn`ogo idiosty`lyu (na materiali poety`chny`x tvoriv V. Kolomijcya ta P. Movchana) [Strokal A. N. Individual-author's word in system of idiastyle art (on a material of Vladimir Kolomiet's and Pavlo Movchan's poetic texts)]. Extended abstract of PhD dissertation, Kyiv, Ukraine.

28. Tarasova, I. A. (2012). Poeticheskiy idiostil'v kognitivnom aspekte [Poetic idiostyle in Cognitive Aspect]. Moscow, Russia: FLINTA.

29. Vinogradov, V. V. (1971). O teorii khudozhestvennoy rechi [On the Theory of Artistic Speech]. Moskow, Russia: Vysshaya shkola.

30. Yurina, Yu. M. (2016). Idiostylj Oleny Telighy [Olena Teliga idiostyle]. Extended abstract of PhD dissertation, Kherson, Ukraine.

І. А. Сидоренко. Поняття ідеостилю в лінгвістичних дослідженнях літературних текстів. Стаття присвячена дослідженню ідіостилю автора як невід’ ємної складової стилістики художнього тексту. Основна увага приділяється підходам до трактування та вивчення поняття ідіостиль, визначенню його місця в лінгвістичних дослідженнях художніх текстів. Виокремлено десять напрямів наукових досліджень: образний, естетично-маркований, структурно-композиційний, прагмасемантичний, комунікативно-когнітивний, лінгвостилістичний, лексичний, лінгвокреативний, лінгвостатистичний, лінгвотипологічний. Виявлено, що вивчення мови художніх текстів крізь призму аналізу індивідуального мовлення автора $\epsilon$ одним 3 найбільш актуальних завдань сучасної лінгвістики. Особливості письменницького ідіостилю аналізуються крізь призму вивчення мовної структури образу автора, естетичної модифікації мовновиражальних засобів на всіх рівнях мови, внутрішньої та зовнішньої будови твору, стилістичних засобів реалізації прагматики авторського мовлення, когнітивного рівня мовної особистості, лексичної ідіосистеми, індивідуально-авторських типологічних моделей. Порівняльний аналіз вказує на те, що одним з найпоширеніших напрямків сучасного дослідження ідіостилю $є$ аналіз авторської концептосфери, стилістичних прийомів, синтаксису та індивідуальної лінгвокреативної творчості. Поєднання декількох підходів в рамках одного дослідження дає можливість комплексно описати та виявити переважаючі особливості ідіостилю автора художнього тексту та зрозуміти принципи індивідуального відбору та синтезу мовних засобів. Перспективою дослідження вважається виокремлення наукових підходів до вивчення ідіостилю драми.

Ключові слова: художній текст; авторський ідіостиль; лінгвістичне дослідження; науковий підхід; авторська мовна модель. 